\title{
КУЛТУРНА ПОЛИТИКА ДРЖАВЕ И КУЛТУРА КЊИГЕ
}

\section{Сажетак}

У раду се анализира културна политика државе у Републици Србији. Избор циљева у културној политици, креће се од чувања културне прошлости, подстицања стваралаштва, развијање веза са међународним културним организацијама. Остваривање циљева културне политике неодвојиво је од избора средстава а она су разнолика. У другом делу се одређује појам културе књиге као начин на који се једно друштво (нација) односи према свим елементима стварања, ширења и коришћења књиге. У том погледу постоји низ унутрашњих посредника између писца и читаоца (штампарија, издавач, књижара, библиотека, књижевни догађаји, читаоци) као и однос спољашњих чинилаца (не)подстицања културе књиге (држава, влада, породица, образоввне установе, медији).

Кључне речи: културна политика, култура књиге, образовање, медији, Република Србија.

Држава је током већег дела свог постојања увек била значајан чинилац културног и уметничког живота друштва. Једна од њених основних функција је, јуче као и данас, брига за развој културе. Сигурно је да се недемократска и демократска држава није једнако односила према култури и уметности, а самим тим ни доносиоци одлука о културној политици нису били бирани на исти начин. Чињеница је да се држава «мешала» на разне начине у културни и уметнички живот, зато што су то и развојна питања друштва. То су јој омогућавали право на доношење закона, стварање институција, значајно финансирање културног и уметничког стваралаштва - буџетски или путем подршке културних пројеката. Како су култура и уметност «производи» јавног добра сваког друштва, држава је у обавези да подржава облике стваралаштва који су «елитни» по свом карактеру али припадају националном фон- 
ду културе. Отуда стара пракса да се институције културе и уметници обраћају државним органима за материјалну и правну подршку.

У теоријским истраживањима постоји сагласност око кључног елемента културне политике: то је подручје усмеравања културног живота једног друштва са становишта одређених циљева и уз помоћ одговарајућих средстава. Шира разматрања појма културне политике захтевају прецизирања значења културе (универзалистичко, социјално утемељење, национални израз). Независно од дефиниције културе, усмеравање културног постојања једне државе није оствариво без идеје о континуитету. По суду Карла Манхајма (Есеји о социологији културе), "ништа што се појавило у културном процесу не може напросто ишчезнути већ у измењеном облику улази у касније структуре". Отворено је питање у којој мери идеју о континуитету обликују институције културе и стваралачке личности.

Формулисање циљева културне политике мора да пође од затеченог стања у култури, од аналитичког инвентарисања културне ситуације. Број културних институција (библиотека, издавача, позоришта, музеја, кинематографије), структура запослениху култури, просторни распоред културе, остварења културних програма и пројеката само су почетни кораци у конципирању културне политике. Замисао основних циљева представља други кључни елеменат усмеравања културног развитка. Планови у култури садрже приоритете. У неким друштвеним приликама приоритет ће се дати државном интересу у култури а у другим општинским или појединим делатностима културе (позориште, библиотека, филм, итд).Са тог становишта, не може се избећи питање начина прихватања културних програма и културних акција, као ни испитивање улоге и оправданости културних установа, вредновање њиховог рада, промену културних потреба али и владајућих механизама одлучивања.

Избор приоритета у културној политици, последица је система одлучивања. Распон циљева креће се од чувања културне прошлости, подстицања стваралаштва, развијање веза са међународним културним организацијама.

Остваривање циљева културне политике неодвојиво је од избора средстава а она су разнолика: систем финансирања, законодавни прописи, идејно-политичка оријентација, награђивање, избор кадрова, стручна истраживања. О средствима може да се говори као 
о стимулативним (заштита, стипендије, награде, откуп) сузбијајућим (порези, законске забране, моралне осуде).

Од дефинисаних циљева и изабраних средстава културна политика може бити прагматска или елитистичка. Стваралачки део културе није елитизам у односу на функционални или традиционални ("освојена култура") концпет културе. Најчешће се елитна култура везује са ремек-делима културе. Вредност културе одређују велике стваралачке личности, које се појављују ненадано и не могу се разумети као заједничко достигнуће нације.

Два најважнија питања културне политике су: 1) ко и како одлучује о пословима у култури, о јавном интересу у култури?, 2) како се финансирају културне делатности?

Постоји неколико начина финасирања културе и уметности: 1) буџет, 2) тржиште, 3) задужбине, фондови, фондације, 4) спонзори, донатори, 5) поклони. Модерна држава посредством буџета финансира оне културне институције које су од националног интереса и које углавном чувају културно наслеђе. То су националне библиотеке, музеји, позоришта, опере, архиви, установе за заштиту споменика. Разуме се, да ове установе културе не могу финансијски да опстану без материјалне помоћи из државне касе. Држава није само влада и парламент, већ и њена вертикална организација - покрајине, општине, локалне заједнице - које такође утичу на финансирање културе.

Друго важно питање културне политике је идентификација субјекта одлучивања. Ко одлучује о културном развитку? Постоје три нивоа одлучивања у култури: 1) одлучивање на релацији држава - култура, 2) одлучивање у културним установама (делокруг и садржај), 3) одлучивање у приватним установама културе. Први ниво одлучивања најчешће припада личности културе која припада политичкој партији, други и трећи је ствар менаџера културе. Саврмене концептуализације културне политике на свим нивоима укључују поред државе и професионална удружења, корпорације, цивилно друштво и најширу јавност. Разуме се, ниједан тип одлучивања не гарантује успешни резултат. Отуда потреба за евалуацијом културне политике Евалуација у култури има две функције: треба да унапреди квалитет одлучивања, као и да побољша комуникацију између оних који доносе одлуке и оних на које се одлуке односе. Када је реч о културним програмима, метод евалуације служи да се прекине са културним програмима који 
не остварују постављене циљеве, да се побољшају програми који су у току реализацију, да се побољшају програми који су у припреми, да се унапреди способност управљања културним установама.

УРепублициСрбији, културнуполитикудоносиВлада, односноМинистарство за културу. У оквиру Министарства постоје сектори за поједина питања: 1) културно наслеђе и библиотечка делатност, 2) уметничко стваралаштво и културна индустрија (визуелна уметност, музичка уметност и дискографија, сценска и музичко-сценска делатност, кинематографија и мултимедији, инспекцијски послови у кинематографији), 3) међународни односи и европске интеграције, 4) финансијски послови и инвестиције.

У свим секторима обављају се студијско-аналитички, управни, управно-надзорни послови. Две основне функције Министарства су да прати стање у одређеној области и да предузима мере за унапређење.

Установе културе на буџету Републике Србије су: Народна библиотека Србије, Библиотека Матице српске, Архив Србије, Народни музеј, Југословенска кинотека, Историјски музеј Србије, Етнографски музеј, Музеј савремене уметности, Музеј примењене уметности, Музеј позоришне уметности, Природњачки музеј, Музеј жртава геноцида (Крагујевац), Галерија Матице српске, Републички завод за заштиту споменика културе, Народно позорише, Београдска филхармонија, Ансамбл Коло, Институ за филм, Завод за проучавање културног развитка.

\section{Култура књиге}

Ако култура човека обухвата интелектуалност, моралност, осећајност онда је књига њен услов. Књига заузима једно од основних места у свакој националној култури. Али шта подразумевамо под културом књиге?

На првом месту какво је значење књиге у културној свести одређене нације. Број објављених књига показује степен културног развитка (према стандардима УНЕСК-а, сваки штампани материјал преко 49 странице може да се назове књигом.) Књига по садржају може да буде: уметничка научна,школска (уџбеници), техничка, популарна, књига за децу.

О култури књиге у друштву судимо и на основу два важна показатеља. Какав је начин мишљења, говора, понашања према књизи. Да ли је она међу водећим вредностима културе? Други важан показатељ је однос према институцијама у којима књига има значајну улогу: породица, црква, школа, држава. 
Појам културе књиге можемо да одредимо као начин на који се једно друштво (нација) односи према свим елементима стварања, ширења и коришћења књиге. У том погледу постоји низ унутрашњих посредника између писца и читаоца (штампарија, издавач, књижара, библиотека, књижевни догађаји, читаоци) као и однос спољашњих чинилаца (не)подстицања културе књиге (држава, влада, породица, образоввне установе, медији).

Култура књиге започиње од онога који пише књиге -књижевника односно научника (писаца). То су увек били даровити појединци или мање групе истраживача. Током историје културе књиге, број посредника између писца и публике се увећавао.

На првом месту је појава издавача, пословне организације која се бави примањем, избором и објављивањем књига. Издавач може да буде држава, и разне приватне организације. Следећа посредничка установа је штампарија.

Прва институција са којом се суочава књижевник са својим написаним делом је издавач. У Србији први издавач била је државна штампарија а потом се јављају књижари - издавачи. Први књижари били су браћа Поповић 1870. а у Србији прву производњу књига започиње Љуба Јоксимовић 1890. године (објавио целокупна дела Светозара Марковића). Двојица највећих књижара издавача били су Геца Кон (објавио за 40 година око 3.000 наслова) и Светислав Цвијановић.

Поред књижара издавача утемељује се традиција задружноггрупног идавања књига. Матица српска у Пешти оснива се 1826. а Српска књижевна задруга 1892. године. Поред књига издају се и књижевни часописи, новине, прегледи (књижевна периодика).

У наше време издавањем књига баве се и друге културне установе: универзитети, научни институти, верске организације, као и велики број приватних издавача. Данас се и новинске куће појављују као велики издавачи (Политика, Новости...).

Штампање Октоиха 1493. године, узима се као прва штампана књига на српском језику. Континуирано штампање почиње у кругу Угарских Срба. Захарије Орфелин објављује први српски часопис 1785. уз помоћ бакроресца Христифора Жефаровића 1785. године.

По неким подацима, издавач и књиговезац Григорије Возаревић, објавио је прву књигу у Србији са насловом «Србска стихотворенија» а касније штампао и књигу Доситеја Обрадовића «Живот и прикљученија». 
Библиотека (читалишта) је неодвојива од рукописа и штампања, издавања књиге. Библиотека скупља књиге (рукописе, новине, часописе, фотографије), објављује књиге, даје на коришћење. Библиотечки рад подразумева каталогизирање, структуирање, класификовање, итд.

Библиотекари треба да буде аниматор - разговара са читаоцем, приступа читаоцу, открива интересовања. Библиотека организује изложбе, концерте, предавања, течајеви, пројекције. Она штампа своје билтене, прегледе, књиге.

Прва јавна библиотека основана је у Београду Народна библиотека 1832. године. Друштво србске словесности оснива библиотеку 1842. Србски лицеум 1844. а Читалиште београдско 1846. Библиотека Матице српске основана је у Пешти 1838. («књигохранилиште»).

Средином XIX века у градовима Кнежевине Србије регистровано је око 42 читаонице. После 1945. у Србији расте број библиотека (поред јавних, оснивају се струковне, школске, омладинске...) Почетком XIX века читалачку публику чини образовано грађанство, учитељи, свештенство, официри, трговци. Са ширењем писмености увећава се и круг читалаца.

Дакле, током XIX века у Србији се оснивају и развијају све кључне институције неопходне за укорењивање културе књиге и задовољавање читалачких потреба. У XX веку, упркос бројним државним и политичким проблемима успостављају се организационе мреже установа и организација културе књиге (хоризонтално и вертиклано повезивање); осавремењује се простор и опрема установа културе које се баве штампањем и ширењем књиге.

Књижара је организација која набавља и продаје књиге. Међутим, поред чистих књижара у којима се продају само књиге постоји и велики број комбинованих књижара. Оне се баве продајом и друге робе као што су папирни канцеларијски материјал, уметничких слика и других предмета. Постоје и књижаре антикварнице. Данас се књига може купити у самопослугама, бензинским пумпама и новинским кисоцима.

Књижара може да прошири своје културне функције. У њој могу да се организују сусрети писаца и публике, да се формира клуб пријатеља књижаре, да постане информативни и образовни центар.

У свакој националној култури одржавају се књижевни догађаји: сајмови књига, смотре, приредбе, манифестације, награде. Те догађаје организују република, општине, књижевна удружења, шко- 
ле, библиотеке, и друге установе културе. У српској култури књиге одржавају се мањи и већи сајмови књига. Посебно треба истаћи Међународни београдски сајам књига.

Шездесет година континуиране присутности у културном и друштвеном животуБеограда, Србије (и Југославије), Балкана, Европе па и света, чини ову приредбу једном од најстаријих и најзначајнијих манифестација културе у широким географским оквирима. Оснивач Београдског сајма књига је Град Београд, манифестацију приређује Одбор Београдског међународног сајма књига, а њен извршни организатор је Београдски сајам.

Основни циљ Сајма књига као издавачке смотре је пружање могућности свим локалним, регионалним и међународним актерима који учествују у производњи и пласману књиге - ауторима, издавачима, књижарима, библиотекарима, дистрибутерима, и другим, да изложе своја нова издања, да се сусретну, размене идеје и искуства, успоставе контакте и склопе пословне договоре.

Београдски сајам књига има предисторију у српској култури која је мање позната широј јавности. Значајно је прибележити да је прва изложба књига у Београду одржана на Ђурђевдан 1893. године, а наредна 9 година касније - 12. и 13. октобра 1902. У току одржавања Првог свесоколског слета Краљевине Југославије, од 7. јуна до 1. јула 1930, Удружење књижара и издавача из Београда је организовало сајам књига на којем су сва издања продавана са попустом од 30 одсто. Овом приликом штампан је и посебан каталог свих издања, а информације о овом догађају објавио је дневни лист „Политика“ 4. јуна и потом у троброју од 8, 9. и 10. јуна 1930. године. Међу укупно тринест учесника Сајма издвајају се већи београдски издавачи: Графички институт „Народна мисао“, књижарнице Геце Кона, „Нолита“, „Напретка“, књижарница Рајковића и Ђурковића, Свесловенска књижарница, књижарница Српске књижевне задруге, књижарница Цвијановића. Будући да су павиљони старог Београдског сајмишта изграђени тек 1937. године, изложбени простор налазио се испред београдских књижара, али и на шпедитерским колима која су крстарила градом. Затим су „Дани књиге“ организовани у уметничком павиљону „Цвијета Зузорић“ на Калемегдану (1932), окупивши већи број учесника из Београда, Новог Сада, Загреба, Сарајева, Никшића, Сплита. Ова манифестација организована је потом сваке године у првој недељи децембра, бележећи раст - како броја излагача, тако и представљених 
издања, али и посетилаца. Године 1935, термин одржавања враћен је у месец јун. Смотра књига је први пут на данашњем Старом сајмишту одржана као пратећа манифестација, 1937. године, од 11. до 21. септембра, у оквиру Првог београдског сајма узорака. Такође у оквиру сајма узорака, одржан је опет као пратећа манифестација сајам књига, у Задужбини Николе Спасића, од 7. до 17. септембра 1939. Последњи пут смотра књига у Краљевини Југославији одржана је у септембру 1940. године. (Милутиновић, Из монографије 60 година београдског сајма књига у штампаним медијима).

Сви ови институционални посредници снажно утичу на формирање читалачке публике и развој читалачких потреба. Са ширењем писмености увећава се и круг читалаца.

Важно место културне политике према књизи је развој потреба за читањем. То подразумева свест о културним потребама али и знања о разликовању стварних (основних) и вештачких. У хијрархији потреба стваралаштво је облик самоактуализације личности а то је потреба највишег реда. Потребе за читањем нису егзистенцијалне, али су неопходне за развој личности, за професионалну делатност и за функционисање и развој друштва. Идентитетске потребе су део Потреба за читањем је део идентитетског бића човека и нације.

Културна политика садржи један правац утицаја на обим и садржај потреба за иитање књига. Извесно је да постоји њихов развој и да се може утицати на њихов смер и интензитет. Али културни утицаји се остварују и у породици, групи у којој се креће, у школи, у медијима могу да постоје повољни и ометајући подстицаји прихватања знања и вредности. Ипак, најпресуднији утица на читалачке потребе у оквиру културне политике имају библиотеке. У том погледу прилике нису задовољавајуће. Примера ради, почетком 1990. године, у Србији је било око 1000 библиотека (Војводина 300). Број библиотека опада. Међународни стандард је 2-3 књиге по глави становника.У Србији, 1,40. Мрежа библиотека је неуједначана. Има примера да 21 насеље има само једну библиотеку. Овоме треба додати и чињеницу да се повећава број књига који је штампан на латиничном писму. Овај пример речито говори у каквој су вези институције културе и развој потреба за читањем. 


\section{Култура књиге - области примене (задовољавање потреба)}

\begin{tabular}{|c|c|}
\hline $\begin{array}{l}\text { А) Институције } \\
\text { (око } 4.000 \text { у Србији) }\end{array}$ & $\begin{array}{l}\text { Културне и уметничке потребе (емотивне, чулне, } \\
\text { сазнајне, социјалне, васпитне, комуникацијске, } \\
\text { вредносне, лична стваралачка амбиција, забавне) }\end{array}$ \\
\hline $\begin{array}{l}\text { - држава (општина, покр. } \\
\text { репуб.) }\end{array}$ & Културна политика \\
\hline $\begin{array}{l}\text { - сценске уметности: } \\
\text { позориште, опера, балет }\end{array}$ & $\begin{array}{l}\text { Доживљај, сазнање, социјални контакт, лепота, } \\
\text { игра, лична амбиција }\end{array}$ \\
\hline - издавачке куће & $\begin{array}{l}\text { Читање, сазнање, машта, доживљај, лектира, } \\
\text { естетика, }\end{array}$ \\
\hline - музичке агенције & Доживљај, лепота, социјални контакт, \\
\hline - музеји, галерије & Лепота, доживљај, социјални контакт \\
\hline - филмске продуцентске куће & Лепота, сазнање, социјални контакт, музика, машта \\
\hline $\begin{array}{l}\text { Установе за проучавање } \\
\text { културе и чување културног } \\
\text { наслеђа }\end{array}$ & Идентитет, традиција, знање \\
\hline Културни центри & Сазнање текуће културе и уметности \\
\hline Аматерска друштва & Доживљај, социјални контакт, традиција \\
\hline Библиотеке & Читање, доживљај, лепо, лектира \\
\hline \multicolumn{2}{|l|}{ Б) Културни догађаји } \\
\hline $\begin{array}{l}\text {-изложбе: уметничке и } \\
\text { наивне уметности }\end{array}$ & Доживљај, социјални контакт \\
\hline - фестивали & Доживљај, сазнање, социјални контакт \\
\hline - инострана гостовања & Доживљај, знање, социјални контакт \\
\hline \multicolumn{2}{|l|}{$\begin{array}{l}\text { В) Индивидуални наступи } \\
\text { уметника }\end{array}$} \\
\hline Књижевник, глумац, певач..... & Доживљај, сазнање, социјални контакт \\
\hline \multicolumn{2}{|c|}{\begin{tabular}{l|l} 
Г) Култура забаве & \\
(популарна култура) & \\
\end{tabular}} \\
\hline - колекционарство & Потреба за реткошћу, оригинал-копија \\
\hline $\begin{array}{l}\text { - народно стваралаштво: } \\
\text { наивни сликари, музичари, } \\
\text { домаћа радиност... }\end{array}$ & Доживљај, традиција, народни обичаји \\
\hline \multicolumn{2}{|l|}{$\begin{array}{l}\text { Д) Медији (новине, радио, } \\
\text { тв, ИТ) }\end{array}$} \\
\hline Емисије о култури књиге & Радозналост, забава, сазнање, доживљај \\
\hline Текстови о књизи & \\
\hline
\end{tabular}




\section{Ко све треба да брине о култури књиге?}

Држава, покрајина, општина. Правни оквир културе књиге обезбеђује правилност и одређени ниво очекивања у функционисању институција које делују у пољу књиге.. Важећи правни основ за обављање културне делатности у Србији је заснован на веома широком сету различитих закона и подзаконских аката.

Књига је роба али и културно или уметничко добро. Уколико се културна политика оријентише на робни карактер културног производа, књиге, онда ће јачати комерцијализација, а са њом пада квалитета културног стварања. У супротном, држава треба да помогне вредна дела од трајне вредности. У оквиру државе, важан део културних функција припада градским општинама и покрајини. Ови државни органи својим буџетима помажу инфраструктуру културе као и културно-уметничке програме. Они се обраћају држави за финасијску помоћ. С друге стране, идеолози тржишта, а и пракса ширења тржишних односа у свим областима друштва, налаже обраћање културе тржишту за помоћ. Никле су агенције за маркетинг, видео спотове, пи-арови.

Шта држава финасира у култури књиге у условима јачања тржишта? Да препусти културу laissez faire? Да системом пореза одбрани аутентичне вредности културе и уметности?

Школа- наставни планови и програми. Култура нације не може да опстане без система образовања. Школа је кохезивна институција захваљујући заједничкој култури и националној традицији. Образовање је најстабилнији чувар националне културне традиције.

Функција образовања је да преноси културну тардицију и стваралаштво. Школа је пренослилац културе књиге, истовремно и начине тумачења, доживљавања и разумевања друштва и човека путем књига и предавања.

Образовање преноси знања и културу. То значи да утиче на укупни развој личности ученика, да га припрема за одређене улоге у друштву, да осмишљава непосредно искуство, да обезбеђује преношење и континуитрт културе, да доприноси укупномразвоју друштва, да утиче на културну еманципацију. Образовање је личност културе у постајању, личност у етапама.

Институције - издавачи, библиотеке, књижаре. Без институција није могућан друштвени и културни живот. Установе омогућавају предвидљивост деловања, оне су устаљени начин друштвеног 
деловања и понашања. Утемељене су на традицији, обичајима, навикама, правним прописима и законима. Институције одговарају одређеном друштвеном времену, а када то време прође утврђују се нове инститиције ако старе нису способне да се прилагоде променама.

Издавачи, библиотеке, књижаре су старе институције у култури књиге али и оне подлежу променама. Модерно време захтева да иду према читаоцу а не да га чекају. Издавачка кућа треба да ради на обезбеђивању финансија, да орагнизује широк спектар промоција, да формира листу претплатника, да прави прес клипинг.

То исто важи за библиотеке: припрема плана и програма културних, образовних и пропагандно-информативних анимационих активности, организација: предавања, трибине, саветовања, књижевне промоције, изложбе, филмске пројекције, повезује библиотеку са програмима других установа, планира маркетинг библиотеке, организује програме за потребе других установа, формира клубове љубитеља књиге, истражује читалачке потребе.

Медији. Са продором нових медија (интернет и мобилни телефон) културна политика се индивидуализује у смислу да сваки учесник на мрежи бира и ствара своју културу. Феномен медијске културе који подразумева убрзано приближавање стваралаштва и медија, показује тенденцију дестандардизације и разноликости. Она је по свом карактеру глобализацијска а појединци су истовремено и корисници али и ствараоци културних садржаја. У таквим околностима могућности контакта са изузетно различитим облицима културе и уметности су огромне. Потребно је да преко старих медија државна културна политика максимално утиче на подршку квалитету и аутеничним вредностима у култури.

\section{Изазови културне политике и културе књиге у новим условима}

Продор тржишне привреде. У Србији још од 1971. године, постоји Закон о самосталном обављању уметничких делатности. По том закону десет уметника могло је да оснује уметничко удружење, или радну заједницу са својством правног лица. Законом је омогућено и приватно предузетништво у издавачкој делатности. Аутор дела може да изда своју књигу на коју има ауторска права. 
Закон о самосталном обављању делатности у култури крајем седамдесетих омогућавао је приватно предузетништво у области културе: књижаре, галерије, антикварнице.

Од првих облика приватног предузетништва у култури Србије до данас, учињен је крупан развојни корак. Све се више шири и све потпуније правно нормативизује. Транзиција у култури је на прво место поставила приватизацију. Мора се приметити да она није истоветна у привреди и култури и уметности. Држава ће и даље остати власник водећих националних установа у култури (неће бити препуштени тржишту) али ће низ мањих установа културе бити приватизована уз ширење простора за стварање нових приватних установа у култури.

У улози финансијера културних пројеката могу се појавити грађани ињиховеорганизације. Са становиштатрајности материјалног помагања културног стваралаштва могу се разликовати задужбина, фондације, фондови, меценатство, донаторство, спонзорство. Ове установе се разликују по начину оснивања, управљања, одређивања циљеве, политике материјалног помагања (Аврамовић, 1992).

Унапређивање законских регулативних механизама зависи и од развоја тржишних односа. Тржиште једнако важи и за културу као и за друге делатности. Лукративност (профит) је мотив приватног предузетништва и у култури, а остварује се путем тржишта.

Критичари комерцијализације, оспоравају чињеницу да је књига и роба која има своју цену на тржишту. Њима смета што је профит део производа који се именује као књига. Свака књига је културно добро и задовољава нечије културне потребе. Њен пут до читаоца је и у социјализму и у капитализму посредован тржиштем, новцем и профитом. Издавач улаже у производ звани књига и очекује зараду. Дакле, поред културног добра књига је и роба која се на тржиту продаје или не продаје. Ово су чињенице које се могу констатовати здравим разумом.

Глобализација. Потребно је разликовати дугорочни и краткорочни циљ глобализацијске културе књиге. Када је реч о овом другом циљу, онда се мора подвући јачање тривијализације књижевности. То је онај део културе који Питирам Сорокин именује као чулна култура која се састоји из три варијетата од којих су значајна два: А) пасивно-паразитски експлоатише и користи спољну стварност («Уживај 
у данашњем дану», «Живот јер кратак»), Б) цинични користи свет стављањем и скидањем маски (лицемери, сналажљиви, послушни).

Талас забаве, игре, спорта, уопште духовно празног живота уз материјалну похлепу је оно кључно обележје савременог друштва и културе. Мед дана, сласт свакодневнице је постало суштинско, а оно што је духовни напор, идејни рад је гурнуто на маргину, не нешто непотребно. Ериксен је тачно приметио да «савремена култура страшно хита, а нигде не стигне» (Eriksen, 2003). Ова преовлађујућа култура забаве већ се именује као «кокаколизација», «мекдоналдизација» стила живота. На удару су друштва са јаком традицијом културе књиге.

Нови медији (ИТ сектор). Постоје мишљења да селидба књижевности на интернет угрожава језик и књижевност, да умањује вредност писане речи, потискује читање врхунска дела. Једном речју, најављују смрт оне књиге какву знамо од Гутемберга. Нестаће наш осећај за уметничко-исторјску дубину и непрекидност времена, а наше читалачко Ја утопиће се у море мрежа са морем интерактивности.

Други верују да је реч о прилагођавању књижевности новим технологијама. Присталице е-књиге, СМС роман (књига у електронској форми) сматрају да је дигитална књижевност заправо нови жанр. То су текстови писани за компјутере, таблете, мобилне телефоне. Писци ове књижевности се прилагођавају страницама, екранима, вебсајтовима, «прозорима».. Али књига неће ишчезнути јер оно што се појави у цивилизацији тешко нестаје.

Реч је о хипертексту, који не може да се штампа а који нуду брјне линкове са другим текстовима, који укључују снимке, анимације и друге садржаје. Другим речима, култура књиге се индивудуализује.

\section{$\mathbf{X} \times \mathbf{X}$}

Клтурна политика сваке државе посвећује већу или мању пажњу култури књиге. Са развојем друштва увећава се и усложњава број посредника између аутора (писца) и читалаца. Дискусија и кризи књиге и читања повезна је са концептом културне политике на свим нивоима ( држава, институције, медији, образовање) али и са институцијама у пољу културе књиге. Будућност књиге и читања је повезана са одгвором који ће сви учесници у култури књиге дати на савремене изазове тржишта, глобализације и информатичких технологија. 


\section{Литература}

Аврамовић, 3. (1992): Задужбине, легати, фондови, фондације у култури Србије, Завод за унапређивање културног развитка Србије, Београд

Аврамовић, 3. (2007): Култура, Завод за уџбенике, Београд

Аврамовић, 3. (2011): Социолошка осмтрачница културе и образовања, Рашка школа, Београд

Марковић, Ж. Слободан ( 2011): Сто година друштва за српски језик и књижевност, Чигија штампа, Београд

Милутиновић, И. (2015): 60 година сајма књига у штампаним медијима, Београдски сајам, Београд

Rot, P. (1996):Sponzorisanje kulture, Clio, Beograd

Поповић Александар, (1958) Приручник из историје библиотека, Београд

Развојни пут Народне библиотеке СР Србије, (1973) Београд

Вранеш Александра (2001): Основи библиографије, Народна библиотека, Београд

Eriksen T.H. (2003): Tiranija trenutka, Beograd, XX vek

Sorokin, P. (2003): Društvena i kulturna dinamika, Podgorica, CID

\section{Zoran Avramović}

\section{CULTURAL POLICY AND CULTURE OF THE BOOK IN SERBIA}

\section{Summary}

This paper examines the relationship of cultural policy in the Republic of Serbia to the culture of the book. The concept of cultural policy is defined as a combination of goals and priorities of cultural development, with the relationship not only related to state institutions, but also to all organizations that deal with this activity. The goals of cultural policy are determined by a democratically elected government with less or more support from the relevant public, and the means for achieving the defined goals are the legal order, the forms of financing, the elected staff, the set of institutions (organizations).

The cultural of the book covers all actors involved in producing and expanding the book, all agents (publishers, bookstores, libraries, trade fair and other events related to the book) between the creator and the reader. The state's cultural policy is partly responsible for the status of the book in society. This equally applies to education policy. The fact is, however, that the modern market influences the attitude of the society towards the book. In the final part, the assessment of the key importance of the book culture in the conceptualization of cultural policy in the Republic of Serbia is underlined.

Key words: cultural policy, book culture, libraries, Republic of Serbia. 